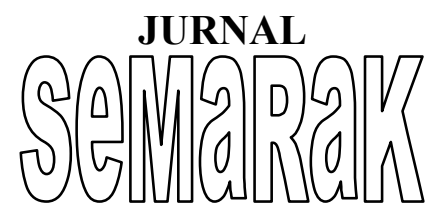

P-ISSN 2615-6849 E-ISSN 2622-3686

Semarak,Vol. 1, No.3,Oktober 2018, Hal (78-87)

@Prodi Manajemen Fakultas Ekonomi Universitas Pamulang

\title{
PENGARUH SUMBER DANA PIHAK KETIGA DAN CURRENT RATIO TERHADAP RETURN ON ASSETS (ROA) PADA PT BANK NEGARA INDONESIA, TBK TAHUN 2009 - 2016
}

\author{
AchmadAgusYasinFadli ${ }^{1}$ \\ Staf Pengajar Universitas Pamulang
}

Email : agusfadli70@yahoo.com

\begin{abstract}
Abstrak
Sumber Dana Pihak Ketiga merupakan dana yang berasal dari masyarakat dan sumber dana terbesar yang paling diandalkan oleh bank. Perusahaan perbankan perlu melakukan pengelolaan Sumber Dana Pihak Ketiga dengan baik, sehingga menghasilkan dan dapat digunakan untuk kegiatan operasional bank ter sebut. Apabila Current ratio stabil maka akan mencapai tingkat Return on assets yang maksimal. Penulis melakukan Penelitian pada PT Bank Negara Indonesia, Tbk. Tujuan penelitian ini untuk mengetahui Sumber Dana Pihak Ketiga,Current ratio dan pengaruhnya terh adap Return on assets (ROA).

Metode penelitian yang digunakan dalam penelitian ini adalah metode deskriptif kuantitatif yang dituangkan dalam angka-angka dengan menggunakan uji asumsi klasik, uji hipotesis berupa uji regresi berganda,

uji korelasi berganda, uji koefisien determinasi serta uji $t$ dan uji $f$ untuk menguji secara parsiala dana simultan.

Populasi dalam penelitian ini adalah seluruh laporan keuangan pada PT Bank $N$ egara Indonesia, Tbk yang terdaftar di Bursa Efek Indonesia (BEI). Sampel yang digunakan berupa laporan Neraca dana laporan Laba/Rugi pada periode tahun 2009 sampai dengan 2016.

Hasil penelitian ini dilihat dari uji $t$ menunjukkan bahwa Sumber Dana Pihak Ketiga tidak berpengaruh terhadap Return on assets. Sedangkan Current ratio be rpengaruh terhadap Return on assets PT Bank Negara Indonesia, Tbk periode 20092016. Saran bagi Penulis selanjutnya agar mengembangkan lebih lanjut penelitian mengenai Sumber Dana Pihak Ketiga dengan menambahkan jenis rasio keuangan lainnya agar hasil penelitian lebih berkembang.
\end{abstract}

\section{Kata Kunci : Return on assets (ROA), Sumber Dana Pihak Ketiga Dan Current Ratio.}

\section{I.PENDAHULUAN}

\section{PENDAHULUAN}

Kebutuhan masyarakat akan pe mbiayaan sekarang ini semakin tinggi,se iring dengan perkembangan teknologi $b$ erkembang pula kebutuhan yang semaki $\mathrm{n}$ meningkat mengikuti arus perkemban gan zaman. Sehingga perkembangan kegiatan perekonomian atau perkembangan kegiatan bisnis suatu 
perusahaan pun semakin meningkat. Perbankan merupakan salah satu jenis usaha yang ikut meningkat dan sangat dibutuhkan oleh masyarakat. Peran utama bank sebagai intermediasi keuangan adalah mengalihkan dana dari pihak yang kelebihan dana (surplus) $\mathrm{k}$ epada pihak yang kekurangan dana (def icit) di samping menyediakan jasajasa keuangan lainnya.

Menurut Kasmir (2012:12), pengertian bank yaitu "Lembaga keuangan yang kegiatan utamanya adalah menghimpun dana dari masyarakat serta memberikan jasa bank lainnya". Perusahaan perbankan mempunyai tiga sumber

dana.Dana pihak kesatu yaitu dana yang bersumber dari bank itu sendiri,dana pi hak kedua merupakan dana pinjaman ya ng bersumber dari lembaga lainnya, dan dana pihak ketiga merupakan dana yan $\mathrm{g}$ dihimpun oleh masyarakat sekaligus $\mathrm{s}$ umber dana yang terbesar yang paling diandalkan oleh bank. Menurut Frianto Pandia (2012:9), pengertian sumber dana pihak ketiga yaitu "dana yang berasal dari masyarakat yang dihimpun dalam bentuk giro (demand deposit), tabungan (saving deposit) dan deposito (time deposit)". Menurut Irham Fahmi (2012:121), rasio lancar (current ratio) adalah ukura $\mathrm{n}$ yang umum digunakan atas solvensi $\mathrm{j}$ angka pendek,

kemampuan suatu perusahaan memenuhi kebutuhan hutang ketika jatuh tempo.R asio profitabilitas yang menunjukan per bandingan antara laba(sebelum pajak) dengan total aset bank, rasio ini mengga mbarkan tingkat efisiensi pengelolaan as et yang dilakukan oleh bank yang bersa ngkutan salah satunya adalah Return $O$ $n$ Assets (ROA) (Slamet Riyadi, 2006:56).

Semakin besar nilai ROA maka semaki n baik pula kinerja perusahaan,karena re turn yang didapat perusahaan semakin $b$ esar. Apabila return on assets (ROA) meningkat,

berarti profitabilitas perusahaan meningk at,

sehingga dampak akhirnya adalah profit abilitas yang dinikmati oleh pemegang $\mathrm{s}$ aham.

Total dana pihak ketiga pada tahun 2016 sebesar Rp 453,5 triliun atau tumbuh 140,6\% dibandingkan tahun 2009 yaitu sebesar $\mathrm{Rp}$ 188,4 triliun. Giro mengalami pertumbuhan tertinggi yaitu sekitar $\quad 172,0 \%$ menjadi $\mathrm{Rp}$ 122,6 triliun dari $\mathrm{Rp} 45$ triliun di tahun 2009. Tabungan tumbuh 169,7\% menjadi $\mathrm{Rp} \quad 158,6 \quad$ triliun dari $\mathrm{Rp}$ 58,8 triliun di tahun 2009.Deposito tum buh $82,4 \%$ menjadi Rp 154, 2 triliun dari $\mathrm{Rp} \quad 84,5$ triliun di tahun 2009. Total dana pihak ketiga yang mengalami penurunan tertinggi pada tahun 2010 yaitu sekitar 3,1\% dilihat dari tahun sebelumnya.

Current ratio pada tahun 2016 mengalami inflasi sebesar 18\% dibanding tahun 2009 yaitu $1,11 \%$. Kenaikan tertinggi terjadi pada tahun 2010 yaitu tumbuh sebesar $6,3 \%$ menjadi $1,18 \%$ dari $1,11 \%$ pada tahun 2009 .

Return on assets (ROA) pada tahun 2016 tumbuh sekitar 58,8\% dari $1,7 \%$

pada tahun 2009 menjadi $2,7 \%$

pada tahun 2016. Nilai ROA selama 8 tahun terakhir mengalami fluktuasi terendah pada tahun 2012 yaitu sekitar $0,68 \%$ dibanding tahun sebelumnya yang memiliki nilai ROA 2,95\%.

Berdasarkan uraian di atas, maka Penulis tertarik untuk membuat judul penelitian dengan judul "Pengaruh Sumber Dana Pihak Ketiga Dan Current Ratio Terhadap Return On Assets (ROA) 
Pada PT Bank Negara Indonesia, Tahun 2009 - 2016".

\section{TINJAUAN PUSTAKA Manajemen Keuangan}

Manajemen keuangan adalah se gala kegiatan perusahaan yang bersangkutan dengan $\mathrm{p}$ erencanaan, perolehan, pemanfaatan dana dan menggunakan da na secara efisien sesuai tujuan yang diinginkan. Manajemen keuangan juga dapat diartikan seni dan ilmu, untuk memanage uang yang meliputi pr oses, industrial/leml pasar dan instrument yang terlibat deng an masalah transfer uang di antara indi vidu,bisnis dan pemerintah. Tujuan manajemen keuangan menurut Agus Sartono (2008:15) adalah sebagai berikut :

a. Memaksimumkan Profit

b. Memaksimumkan Kemakmuran Para Pemegang Saham

\section{Bank}

Bank merupakan badan usaha yang bergerak di bidang keuangan yang fungsi utamanya menghimpun dana dan menyalurkannya kembali dana tersebut kepada masyarakat dalam bentuk kredit serta memberikan pelayanan jasa lainnya. Penilaian kesehatan bank telah ditentuka $\mathrm{n}$ oleh Bank Indonesia yaitu kepada ba nk-

bank diharuskan membuat laporan baik bersifat rutin maupun secara berkala me ngenai seluruh aktivitasnya dalam suatu periode tertentu. Sumber-sumber dana bank digolongkan menjadi tiga, yaitu :

a. Dana yang bersumber dari bank itu sendiri

b. Dana yang berasal dari masyarakat

c. Dana yang bersumber dari lembaga lainnya

\section{Sumber Dana Pihak Ketiga}

Sumber dana pihak ketiga digunakan oleh pihak bank untuk dapat dikelola diberdayakan sehingga mengha silkan dan dapat digunakan untuk mem biayai kegiatan operasional bank tersebu t.Sumber dana pihak ketiga yang mendukung kegiatan operasional bank yaitu Simpanan Giro, Simpanan Tabungan dan Simpanan Deposito. Untuk bisa menjaga sumber dana yang bersumber dari masyarakat, pihak bank harus menjaga kepercayaan nasabahnya atas dana yang dititipkan.

\section{Analisis Rasio Keuangan}

Analisis rasio keuangan adalah rasio yang menggambarkan suatu hubun gan atau pertimbangan (mathematcal ronship)

antara suatu jumlah tertentu dengan jum lah yang lain dan dengan menggunakan alat analisis berupa rasio ini akan dapa $\mathrm{t}$ menjelaskan atau memberi gambaran kepada penganalisis tentang baik atau $b$ uruknya keadaan atau posisi keuangan $\mathrm{s}$ uatu perusahaan terutama apabila angka rasio tersebut dibandingkan dengan ang ka rasio pembanding yang digunakan se bagai standar.

Menurut Bambang Riyanto (2001), jenis -

jenis rasio keuangan adalah sebagai beri kut :

a. Rasio likuiditas adalah rasiorasio yang dimaksud untuk menguk ur likuiditas perusahaan (Current ratio, Acid test ratio)

b. Rasioa Leverage adalah rasiorasio yang dimaksudkan untuk men gukur sampai seberapa jauh aktiva perusahaan dibiayai dengan hutang (Debt to total assets ratio, Net worth to debt ratio dan lain se bagainya)

c. Rasio Aktivitas yaitu rasiorasio yang dimaksudkan untuk men 


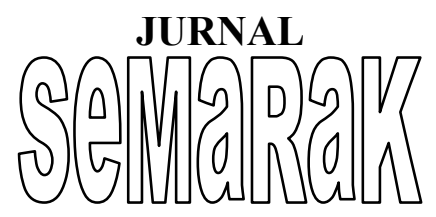

gukur sampai berapa besar efektivit as perusahaan dalam mengerjakan $\mathrm{s}$ umber-sumber dananya

(Inventory turnover,

Average collection period dan lain sebagainya)

d. Rasio profitabilitas yaitu rasiorasio yang menunjukkan hasil akhir dari sejumlah kebijaksanaan dan $\mathrm{k}$ eputusan-keputusan

(Profit margin on sales,

Return on net worth dan lain s gainya)

\section{Current Ratio}

Current ratio adalah salah

indikator dari rasio likuiditas

digunakan untuk mengukur kemam

perusahaan dalam melunasi kewaji $\mathbf{H}$

kewajiban

jangka pendek.Semakin besar perbar

gan aktiva lancar dan hutang lancar se

makin tinggi kemampuan perusahaan $\mathrm{m}$ enutupi kewajiban jangka pendeknya.

Rumus current ratio :

$$
\text { Current Ratio }=\frac{\text { Aktiva Lancar }}{}
$$

Hutang Lancar

\section{Return On Assets}

Return on assets digunakan unt uk mengukur profitabilitas dari total ase t,tanpa mempertimbangkan bagaimana a set didanai.Tingkat pengembalian terhad ap total aset dihitung dengan menambah beban bunga ke laba bersih dan memb agikannya dengan rata-rata total aset.

Rasio ini sekaligus merupakan indikator efisiensi manajerial bank yang mengindikasikan kemampuan manajemen dalam pengelolaan aset-asetnya untuk memperoleh keuntungan. Menurut Lukman Dendawijaya (2009), "bahwa dalam penentuan tingkat kesehatan bank, Bank Indonesia lebih mementingkan penilaian besarnya Return On Assets (ROA) dan tidak memuaskan unsur Return On Equity (ROE). Hal ini dikarenakan Bank Indonesia sebagai pembina dan pengawas perbankan lebih mengutamakan profitabilitas suatu bank yang diukur dengan aset yang dananya sebagian besar berasal dari dana simpanan masyarakat".

Rumus Return On Assets :

R OA = Laba Bersih Setelah Pajak Total Aset

\section{Hubungan Sumber Dana Pihak Ketiga Terhadap Return On Assets}

Sumber dana yang dihimpun ol eh masyarakat sebagai dana pihak ketig a sangat besar pengaruhnya,karena meru pakan sumber dana yang paling diandal kan oleh bank. Sumber dana yang dimaksud adalah simpanan yang didapatkan oleh bank ya ng akan disalurkan kembali kepada mas yarakat oleh bank melalui penyaluran $d$ ana dalam bentuk kredit.Penyaluran dala $m$ bentuk kredit akan memberikan kontr ibusi pendapatan bunga bagi bank yang akan berdampak pada tingkat return on assets (laba) bank.

Pendapatan yang diterima bank dari hasil penyaluran kredit digunakan oleh bank untuk bisa dikelol a diberdayakan sehingga menghasilkan dan dapat digunakan untuk membiayai kegiatan operasional bank tersebut.

Untuk menopang kegiatan bank sebagai penjual uang (memberikan pinjaman), bank harus terlebih dahulu membeli uan $\mathrm{g}$ sehingga dari selisih bunga tersebutlah bank memiliki keuntungan atau laba. 


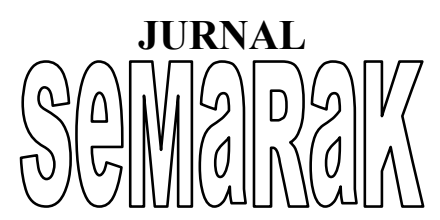

Semarak,Vol. 1, No.3,Oktober 2018, Hal (1-20)

@Prodi Manajemen Fakultas Ekonomi Universitas Pamulang

\section{Hubungan Current Ratio Terhadap Return On Assets}

Rasio lancar

(current

ratio)merupakan rasio yang menunjukka n sampai sejauh apa kewajiban lancar d itutupi oleh aset yang diharapkan akan dikonversi menjadi kas dalam waktu de kat.Perusahaan perbankan harus menjaga kestabilan likuiditasnya agar tetap ama $\mathrm{n}$ serta mencapai tingkat return on asse ts yang maksuimal, hal tersebut akan menjaga kepercayaan nasabahnya atas dana yang dititipkan.

Current ratio yang mengalami kenaikan memiliki pengaruh terhadap return on assets yaitu akan menurunkan nilai ROA, sedangkan current ratio yang mengalam i penurunan maka akan menaikkan nilai ROA. Semakin besar current ratio, maka akan menunjukkan semakin besar kemampuan perusahaan dalam men hi kewajiban jangka pendeknya.

\section{METODE PENELITIAN}

Dalam penelitian ini Penuli: enggunakan penelitian deskriptif kuc atif.Deskriptif kuantitatif adalah pen tan yang dilakukan berdasarkan ang angka yang selanjutnya akan dianali secara statistik.Populasi yang diguna dalam penelitian ini menggunakan lapo ran keuangan berupa neraca dan laba ru gi PT Bank Negara Indonesia, Tbk, sedangkan sampel dalam penelitian ini menggunakan laporan keuangan

PT Bank Negara Indonesia,

Tbk tahun 2009 sampai dengan 2016.

Sumber data penelitian menggunakan data sekunder, data sekunder yaitu data yang diperluka $\mathrm{n}$ untuk mendukung hasil penelitian ber asal dari literatur,artikel dan berbagai su mber lain yang berhubungan dengan ma salah penelitian. Metode pengumpulan da ta dalam penelitian ini menggunakan riset kepustakaan, artinya memperoleh data kepustakaan sebagai landasan teori dalam menganalisis masalah yang diteliti, dengan cara mempelajari buku-buku ilmiah, literature dan media informasi lainnya.

Variabel bebas (Independen) yang digunakan dalam penelitian ini yaitu Sumber Dana Pihak Ketiga sebagai $\mathrm{X}_{1}$ dan Current ratio sebagai $\mathrm{X}_{2}$. Variabel bebas adalah variabel yang me mpengaruhi atau yang menjadi sebab pe rubahannya atau timbulnya variabel teri kat.Sedangkan variabel terikat(dependen) yang digunakan dalam penelitian ini $\mathrm{y}$ aitu Return On Assets (ROA). Variabel terikat adalah variabel yang di pengaruhi atau yang menjadi akibat,kare na adanya variabel bebas.Uji coba dala $\mathrm{m}$ penelitian ini menggunakan bantuan program SPSS Ver. 24 For Windows. Teknik analisis data yang digunakan ant ara lain,(1) Statistik deskriptif, (2)Pengujian Asumsi Klasik meliputi uji normalitas,uji multikolinearitas,uji auto korelasi,dan uji heterokedastisitas,(3)Pen gujian Hipotesis meliputi uji regresi ber ganda,uji korelasi berganda,uji koefisien determinasi $\left(\mathrm{R}^{2}\right)$, uji signifikansi parsial (uji t) dan uji signifikansi simultan (uji f).

\section{HASIL,PEMBAHASAN DAN IMPLEMENTASI MANAJ ERIAL}

Pengujian hipotesis dilakukan $\mathrm{u}$ ntuk mengetahui ada tidaknya korelasi a ntara variabel bebas dengan variabel ter ikat,dan untuk menetapkan dasar dalam menentukan keputusan apakah menolak atau menerima kebenaran dari pernyataa $\mathrm{n}$ atau asumsi yang dibuat. Hipotesis dalam penelitian ini meliputi uji regresi berganda,

uji korelasi berganda,uji koefisien deter minasi,uji t dan uji $\mathrm{f}$.

1) Uji Regresi Berganda 
JURNAL

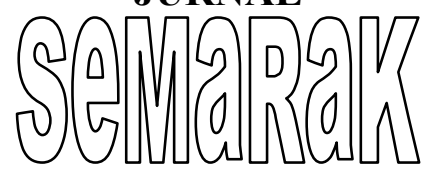

Semarak,Vol. 1, No.3,Oktober 2018, Hal (1-20)

@Prodi Manajemen Fakultas Ekonomi Universitas Pamulang

a. Berdasarkan pengujian menggunakan SPSS Ver. 24, nilai konstanta sebesar Rp 11,659, artinya jika Sumber Dana Pihak Ketiga dan Current ratio nilai nya adalah 0 , maka ROA yang disalurkan ni lainya adalah $\mathrm{Rp}-11,659$.

b. Koefisien regresi variabel Sumber Dana Pihak Ketiga bernilai negatif sebesar -7,565. Artinya terjadi hubungan yang negatif antara DPK dan ROA.

c. Koefisien regresi Current ratio bernilai positif sebesar 13,532. Artinya terjadi hubungan yang positif antara Current ratio dengan ROA.

2) Uji Korelasi Berganda

a. Berdasarkan pengujian menggunakan SPSS Ver. 24, nilai signifikansi hubungan Sumber Dana Pihak Ketiga dengan ROA adalah 0,437> 0,05, maka dapat dikatakan bahwa tidak terdapat hubungan antara DPK dengan ROA. Sedangkan nilai pearson correlation adalah sebesar 0,321 nilai $r$ berada dalam rentang $0,21 \mathrm{~s} / \mathrm{d} \quad 0,40$ artinya tingkat hubungan antara DPK dan ROA termasuk dalam kategori korelasi lemah.

b. Nilai signifikansi hubungan antara current ratio dengan ROA sebesar $0,122>0,05$, maka dapat dikatakan bahwa tidak terdapat hubungan antara Current ratio dengan ROA. Sedangkan nilai pearson correlation adalah sebesar 0,591 nilai $r$ berada dalam rentang $0,41 \mathrm{~s} / \mathrm{d} \quad 0,60$ artinya tingkat hubungan antara
Current ratio dengan $\mathrm{ROA}$ termasuk dalam kategori korelasi sedang.

3) Uji Koefisien Determinasi

Berdasarkan pengujian menggunakan SPSS Ver. 24, nilai R square menunjukkan 0,616 yang berarti bahwa variabel independen (DPK dan Current ratio) mempengaruhi variabel dependen (ROA) sebesar 61,6\% dan sisanya $38,4 \%$ dipengaruhi oleh faktor lain yang tidak dijelaskan dalam penelitian ini.

4) Uji Signifikansi Parsial (Uji t)

a. Berdasarkan pengujian SPSS Ver. 24, Sumber Dana Pihak Ketiga $\left(\mathrm{X}_{1}\right)$ diperoleh nilai $\mathrm{t}_{\text {hitung }}$ sebesar $-1,859$ dengan nilai signifikansi 0,122 dan $t_{\text {tabel }}$ 2,571 . Karena $t_{\text {hitung }}<t_{\text {tabel }}(-$ $1,859<2,571)$ dan signifikansi $>$ $0,05 \quad(0,122>0,05)$ maka $\mathrm{Ha}$ ditolak Ho diterima. Jadi dapat disimpulkan bahwa Sumber Dana Pihak Ketiga tidak memiliki pengaruh terhadap Return On Assets (ROA).

b. Berdasarkan pengujian menggunakan SPSS Ver. 24, Current Ratio $\left(\mathrm{X}_{2}\right)$ terhadap Return On Assets (Y) diperoleh nilai $t_{\text {hitung }}$ sebesar 2,581 dengan nilai signifikansi 0,049 dan $t_{\text {tabel }}$ 2,571. Karena $t_{\text {hitung }}>\quad t_{\text {tabel }}$ $(2,581>2,571)$ dan signifikansi $<0,05(0,049<0,05)$ maka Ha diterima Ho ditolak. Jadi dapat disimpulkan bahwa Current Ratio memiliki pengaruh terhadap Return On Assets (ROA).

5) Uji Signifikansi Simultan (Uji f) Berdasarkan pengujian SPSS Ver. 24, F $_{\text {hitung }}$ pada tabel ANOVA sebesar 4,004 dan nilai signifikansi sebesar 0,09 $(0,09>0,05)$ maka dapat disimpulkan 
bahwa Sumber Dana Pihak Ketiga, Current Ratio secara simultan tidak berpengaruh terhadap Return On Assets (ROA).

\section{Pengaruh Sumber Dana Pihak Ketiga Terhadap Return On Assets Pada PT Bank Negara Indonesia, Tbk}

Berdasarkan hasil perhitungan menggunakan uji $\mathrm{t}$ diperoleh $\mathrm{t}_{\text {hitung }}$ sebesar $-1,859$ dengan nilai signifikansi 0,122 dan $t_{\text {tabel }}$ 2,571. Hal ini menunjukkan bahwa variabel Sumber Dana Pihak Ketiga berpengaruh negatif atau tidak signifikan terhadap Return On Assets pada PT Bank Negara Indonesia, Tbk. Sumber Dana Pihak Ketiga pada PT Bank Negara Indonesia, Tbk selalu mengalami kenaikan yang signifikan setiap tahunnya tetapi berbanding terbalik dengan nilai ROA yang tidak stabil dan mengalami fluktuasi kenaikan dan penurunan nilai pada setiap tahunnya. Oleh karena itu hal tersebut yang menyebabkan nilai DPK tidak berpengaruh terhadap ROA.

\section{Pengaruh Current ratio Terhadap Return on assets Pada PT Bank Negara Indonesia, Tbk}

Berdasarkan hasil perhitungan menggunakan uji $\mathrm{t}$ diperoleh nilai $\mathrm{t}_{\mathrm{hitung}}$ sebesar 2,581 dengan nilai signifikansi 0,049 dan $t_{\text {tabel }}$ 2,571. Hal ini menunjukkan bahwa Current Ratio berpengaruh positif terhadap Return On Assets atau signifikan terhadap Return On Assets. Maka dapat disimpulkan bahwa kemampuan perusahaan dalam melunasi kewajiban jangka pendeknya sehingga akan berpengaruh dengan kenaikan Return On Assets (ROA). Dengan meningkatnya nilai ROA maka perusahaan tersebut semakin baik pula kinerjanya sehingga akan berdampak pada peningkatan profitabilitas yang dinikmati pemegang saham. Perusahaan harus mampu menjaga agar rasio lancarnya berada dalam batasbatas yang dapat diterima, khususnya oleh pihak pemberi dana (investor). Oleh karena itu, variabel Current Ratio berpengaruh signifikan terhadap ROA.

\section{Implementasi Manajerial}

Dalam uji statistik deskriptif nil ai variable $\quad \mathrm{X}_{1} \quad$ (DPK) tidak bervariasi dan cukup rendah deng an hasil rata-rata $\mathrm{Rp}$ 287.693,63,sedangkan nilai $X_{2}(C R)$ dan $\mathrm{Y}$ (ROA) juga tidak bervariasi tetapi untuk nilai rata-rata $\mathrm{CR}$ dan ROA cukup tinggi karena mendekati nilai ma ksimum yaitu mencapai $123 \%$ dan $278 \%$. Pada uji asumsi klasik penelitian ini te lah memenuhi normalitas, tidak terjadi multikolinearitas, autokorelasi dan heterokedastisitas.Pada uji autokorelasi nilai Durbin Watson sebesar 1,837, yakni lebih dari 1 dan kurang dari 3 sesuai dengan syarat Durbin Watson yaitu $1<1,837<3$. Pada uji hipotesis regresi berganda, variabel $\mathrm{X}_{1}$ (DPK) terhadap $\mathrm{Y}$ (ROA) terjadi hubungan yang negatif sedangkan variabel $\mathrm{X}_{2} \quad$ (CR) terhadap Y (ROA) terjadi hubungan yang positif.DPK dan ROA pada korelasi berganda tidak terdapat $h$ ubungan dengan hasil korelasi lemah, begitu juga dengan $\mathrm{CR}$ dan ROAtidak memiliki hubungan tetapi nilai korelasinya sedang.

Pada uji determinasi variabel independe $\mathrm{n}$ (DPK dan CR) mempengaruhi ROA sebesar $61,6 \%$ dan sisanya $38,4 \%$ dipengaruhi oleh faktor lain.Dalam uji $t$ DPK dan ROA tidak ada pengaruh dikarenakan nilai si gnifikansi DPK lebih besar dari syarat signifikansiya itu $0,122>0,05$,sedangkan CR 


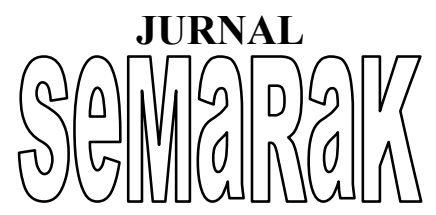

P-ISSN 2615-6849 E-ISSN 2622-3686

Semarak,Vol. 1, No.3,Oktober 2018, Hal (1-20)

@Prodi Manajemen Fakultas Ekonomi Universitas Pamulang terdapat pengaruh terhadap

ROA meskipun yaitu dengan nilai signifikansi $0,049<0,05$. Begitu pula dengan penelitian uji variabel independen (DPK dan CR) tidak memiliki pengaruh terhadap ROA.

\section{KESIMPULAN DAN SARAN Kesimpulan}

1) Dari hasil pengujian secara simultan (Uji f) dapat diketahui bahwa Sumber Dana Pihak Ketiga (DPK) dan Current ratio secara simultan tidak memiliki pengaruh secara signifikan terhadap Return On Assets (ROA) dengan taraf signifikansi lebih dari 0,05 yaitu $0,09>0,05$ dan dilihat dari hasil koefisien determinasi bahwa secara bersama-sama (simultan) DPK dan CR memberikan pengaruh terhadap ROA sebesar 61,6\%. Sehingga dapat disimpulkan ROA PT Bank Negara Indonesia, Tbk pada tahun 2009-2016 dapat dijelaskan oleh DPK dan CR sebesar $61,6 \%$ dan sisanya $38,4 \%$ dipengaruhi oleh faktor lain yang tidak dijelaskan dalam penelitian ini.

2) Sumber Dana Pihak Ketiga tidak berpengaruh signifikan terhadap Return On Assets (ROA). Hal $0,122>0,05$ dan $t_{\text {hitung }}$ lebih kecil dari $t_{\text {tabel }}$ atau $-1,859<2,571 \mathrm{Ha}$ ditolak.

3) Current Ratio memiliki pengaruh signifikan terhadap ROA. Hal ini dilihat dari nilai signifikansi pada uji t yakni lebih kecil dari taraf signifikansi sebesar 0,049<0,05 dan $t_{\text {hitung }}$ lebih besar dari $t_{\text {tabel }}$ atau 2,581>2,571 sehingga Ho ditolak.

\section{Keterbatasan}

1) Periode waktu penelitian dibatasi hanya 8 tahun, yaitu dari tahun 2009 sampai 2016.

2) Rasio keuangan yang digunakan dalam penelitian ini relatif sedikit, hanya 2 rasio saja yaitu Currebt Ratio dan Return On Assets.

3) (Penelitian ini dilakukan pada PT Bank Negara Indonesia, Tbk dengan menggunakan data sekunder dari Bursa Efek Indonesia (BEI).

\section{Saran}

1) Perusahaan harus meningkatkan laba perusahaan setiap tahunnya agar ROA selalu stabil atau tidak mengalami penurunan.

2) Di sisi lain pada variabel Current Ratio berpengaruh signifikan terhadap ROA, namun nilai signifikansi hampir mendekati taraf signifikansi pada uji t. Oleh karena itu harus lebih mampu dalam melunasi kewajiban jangka pendeknya.

3) Bagi para penulis selanjutnya yang tertarik pada penelitian ini, sebaiknya memperpanjang periode penelitian dan menambahkan variabel lain yang dapat mempengaruhi ROA sehingga penelitian ini memiliki hasil yang lebih maksimal dan berkembang.

\section{DAFTAR PUSTAKA}

Alma, Buchari, "Pengantar Statistika", Cetakan Ke-8, Bandung: ALFABETA, 2015 


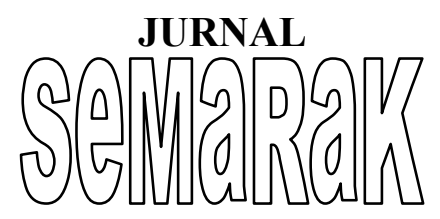

P-ISSN 2615-6849 E-ISSN 2622-3686

Semarak,Vol. 1, No.3,Oktober 2018, Hal (1-20)

(a)Prodi Manajemen Fakultas Ekonomi Universitas Pamulang
Brigham dan Houston, "Dasar-Dasar

Manajemen Keuangan”, Edisi 11, Jakarta:

Penerbit Salemba Empat, 2015

Cahyono, Bambang Tri, "Manajemen

Sumber Daya Manusia”, Jakarta: Badan

Penerbit Ipwi, 1996

Dendawijaya, Lukman, "Manajemen

Perbankan”, Jakarta: Ghalia Indonesia, 2009

Fahmi, Irham, "Pengantar Manajemen

Keuangan”, Cetakan Pertama, Bandung:

Penerbit ALFABETA, 2012

Halim, Abdul dan Mamduh M. Hanafi,

“Analisis Laporan Keuangan”, Edisi 4,

Yogyakarta: UPP STIM YKPN, 2009

Harahap, Sofyan Syafri, “Analisa Kritis

Atas Laporan Keuangan", Jakarta: PT

Raja Grafindo Persada, 2008

Hasibuan, Malayu SP, "Dasar-Dasar

Perbankan”, Jakarta: PT Bumi Askara, 2006

Kasmir, "Pengantar Manajemen

Keuangan”, Edisi 1, Cetakan 2, Jakarta:

Penerbit Prenada Media, 2010

Kasmir, "Manajemen Perbankan",

Jakarta: Rajawali Pers, 2012
Kasmir, "Bank dan Lembaga Keuangan

Lainnya”, Edisi 6, Jakarta: Raja Grafindo Persada, 2013

Kasmir, “Analisis Laporan Keuangan”, Edisi 1, Cetakan Ke-7, Jakarta: Rajawali Pers, 2014

Kuncoro, Mudrajad dan Suhardjono, "Manajemen Perbankan Teori dan Aplikasi”, Edisi 1, Yogyakarta: BPFE, 2002

Martono dan Agus Harjito, "Manajemen Keuangan”, Edisi 1, Cetakan Ke 8, Yogyakarta: Ekonisia, 2010

Moeljadi, “Manajemen Keuangan”, Jilid 1, Bayumedia Publishing, 2006

Muhidin, Sambas Ali, Maman Abdurahman, "Analisis Korelasi, Regresi dan Jalur Dalam Penelitian”, Bandung: CV Pustaka Setia, 2007

Munawir, S, "Analisa Laporan Keuangan”, Edisi 4, Yogyakarta: Liberty, 2010

Pandia, Frianto, "Manajemen Dana dan Kesehatan Bank", Jakarta: Rineka Cipta, 2012 


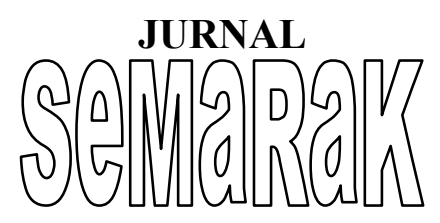

P-ISSN 2615-6849 E-ISSN 2622-3686

Semarak,Vol. 1, No.3,Oktober 2018, Hal (1-20)

(a)Prodi Manajemen Fakultas Ekonomi Universitas Pamulang

Prihadi, Toto, “Deteksi Cepat Kondisi Sugiyono, "Metode Penelitian”, Cetakan

Laporan Keuangan”, Cetakan Pertama, Ke-23, Bandung: ALFABETA, 2016

Jakarta: Lembaga Manajemen PPM, 2008

Sutrisno, "Manajemen Keuangan",

Reeve, James M, \& Warren, Carl W, Yogyakrta: Ekonisia, 2003

"Pengaruh Akuntansi", Buku 2, Jakarta:

Salemba Empat, 2013

Wardiah, Mia Lasmi, “Dasar-Dasar Perbankan”, Cetakan 1, Bandung:

Republik, Indonesia, "Undang-Undang Pustaka Setia, 2013

No. 10/1998 Tentang Perbankan”, 1998

www.bni.co.id

Rivai, Veithzal, Andria Permata Veithzal dan Ferry N. Indroes, "Bank and $\underline{\text { www.bi.co.id }}$

Financial Instituion Management www.idx.co.id

Conventional and Sharia System”, Edisi

1, Jakarta: Raja Grafindo Persada, 2007

Riyadi, Slamet, "Banking Assets And Liability Management" Edisi Ketiga, Jakarta: Lembaga Penerbit Fakultas Ekonomi Universitas Indonesia, 2006

Riyanto, Bambang, "Dasar-Dasar Pembelanjaan Perusahaan”, Yogyakarta: BPFE, 2001

Sartono, Agus, "Manajemen Keuangan Teori dan Aplikasi”, Edisi Ke Empat, Yogyakarta: BPFE, 2008

Sarwono, Jonathan, "12 Jurus Ampuh SPSS untuk Riset Skripsi”, Jakarta: Elex Media Komputindo, 2013 